\title{
CONCEPTION OF CAE SYSTEM SUPPORT FOR PROTECTIVE COATING DEPOSITION PROCESS DESIGN IN AGROINDUSTRIAL COMPLEX
}

\author{
Igor Kravchenko ${ }^{1}$, Maxim Glinskiy ${ }^{1}$, Yury Kuznetsov ${ }^{2}$, Tatiana Cheha ${ }^{1}$ \\ ${ }^{1}$ Russian Timiryazev State Agrarian University, Russia; \\ ${ }^{2}$ N.V. Parahina Orel State Agrarian University, Russia \\ kravchenko-in71@yandex.ru,maximagl@yandex.ru, kentury@yandex.ru, zubik280270@mail.ru
}

\begin{abstract}
Currently in agricultural complex there exists a significant requirement in life time improving of the different processing equipment. One of the most promising and advanced ways to improve the resource of technological equipment is the protective and functional coatings thermal spray deposition for reconditioning and hardening of the core parts and movable operating elements, such as: parts of mixers of variable constructions and purposes, blades and scrapers of different machines, calenders, sliding bearing and mechanical seal parts, tank equipment and heat exchanger work surfaces, high speed centrifugal separator and decanter parts, conveyors and draw plates. Using of the proposed intelligent automated design system (CAE-system) enables considerably decrease costs and time for development of effective resource-saving technological processes of manufacturing coated equipment parts, improve quality and increase designers and technologist labour productivity. The software package being implemented at the same time allows to effectively carry out computational experiments for a comprehensive study and prediction of the resulting coatings of various functional purposes with enhanced physical, mechanical and operational properties. The paper presents the concept, architecture, principles of design and approach to development of the proposed CAE-system and highlights the potential for its further implementation in the practice of processing industries repair facilities and specialized service centres of the agroindustrial complex.
\end{abstract}

Keywords: agroindustrial complex, CAE-system, protective coating, decision support system.

\section{Introduction}

Currently, in the agroindustrial complex (AIC) there is a need for restoring and hardening parts of processing equipment. The analysis showed that $85-90 \%$ of machine parts fail due to mechanical, abrasive, hydroabrasive, corrosion-and-mechanical and oxidative wear, with $75 \%$ of the parts being rejected are repairable. Current trends in the intensification of production processes lead to accelerated wear of parts, and in these conditions the task of restoring and increasing the durability of key parts, components and assemblies of machinery and equipment becomes even more important and relevant. Under these conditions, the real strategy for ensuring the operability of processing equipment in the AIC is to restore and strengthen the parts [1-3].

In economically developed countries the restoration of worn parts is very widely developed. The leading industrial enterprises of the world pay the most serious attention to strengthening and modernizing the technological equipment. The companies that manufacture machines and specialized firms for restoration of worn parts are engaged in the promotion and development of the technology for restoring parts. Restored parts are 1.5-10 times cheaper than new parts, and, as a rule, are not inferior in terms of resources [4-9].

For AIC processing industries, the restoration and hardening of mixing parts of various designs and applications, knives and scrapers of various machines, calenders, sliding bearings, mechanical seals, capacitive equipment of various types and purposes, parts of heat exchanging equipment, parts of separators is relevant. To solve the problems of restoration and hardening different kinds of materials are used, such as $\mathrm{WC} / \mathrm{CoCr}$, stellite, nickel corrosion-resistant steels, WC / Ni, WC / $\mathrm{NiCrBSi}$, nickel alloys (hastelloy, etc.), $\mathrm{Cr}_{2} \mathrm{O}_{3}, \mathrm{Al}_{2} \mathrm{O}_{3} / \mathrm{TiO}_{2}$, Ni, babbit, bronze, $\mathrm{Al}$, WC / MoCrSi [19].

Currently, the technologists involved in the development of technological processes of hardening and/or restoration of parts are facing the following problems[4-9]:

1. there is a very large variety of different parts to be strengthened and/or restored;

2. operating conditions of these parts differ significantly from each other, and the parts themselves are subject to various types of wear;

3 . there are many materials for coating;

4. there are various coating methods. 
A significant increase in the resource is important with the rational use of metal-polymer coatings and powdered hard alloys, which usage is constantly increasing. One of the most promising, modern and effective technological methods of applying composite materials on the surface of worn parts is plasma spraying and plasma surfacing that most fully meet the technical and technological requirements (high productivity, wide possibility of doping applied coatings, large input control range heat in the main and filler materials, the possibility of applying any filler materials, etc.) [2;3;8-10]. Due to the technical and economical advances currently plasma spraying technologies occupy the dominant position on the thermal spray market worldwide, while the other thermal spray methods have became more the niche-technologies [10;11].

Until the mid-1990s, the coating spraying process was controlled using the following iterative procedure: determination of technological parameters, sputtering, and study of the sample properties. This procedure was repeated until samples were obtained with satisfactory characteristics, after which the deposition regimes were fixed. However, the equipment for spraying is very sensitive to wear, and therefore, the application of this method does not allow to ensure the stability and reproducibility of the properties of coatings [12-17].

From the beginning of 2000 the new researches in plasma computational modelling based on modern computational technologies, mathematical methods and big data management approaches were streamlined with an aim to make a plasma spray model qualified for engineering technological computations [18-35].

Despite of undeniable progress reached in plasma spraying modelling designing a plasma spraying process is still a big issue: the complexity of the design of the plasma torch, the complexity of mathematical modeling and the problems of stability of the process of spraying still require many natural and virtual tests [36-40]. A further increase in the efficiency of using plasma spraying is associated with the development of methods and means of automation and computerization of the spraying process. To obtain coatings with the required propertiesit becomes necessary to develop a specialized CAE system $[2 ; 3 ; 10 ; 11 ; 41-43]$.

The objective and scope of the current work is to present the concept, structure, basic assumptions, main technical and technological aspects and possibilities (potential and realized) of the CAE-system designed as a result of series of researches provided by the authors [2;44-48].

\section{Materials and methods}

The main task of the CAE-system is to increase the level of intellectual activity and labour productivity of the technologist and its use allows to design an optimal technological and technical solutions aimed at improving the quality of machine parts, as well as shortening the time and cost of developing technological processes.

The following key elements are necessary for development and implementation of a full-fledged CAE-system of gas-thermal and plasma coatings and the technology of their application:

1. Engineering methodology, reflecting the optimal scenarios for the development of gas-thermal coatings by the technologist and technology of their deposition.

2. Physical and corresponding mathematical models describing all the necessary steps of the engineering methodology.

3. Software and hardware that implements the appropriate mathematical models and linking them into a single CAD system, providing a convenient interface for the technologist to effectively go through all the steps of the engineering methodology and, ultimately, develop a gas-thermal coating and its application technology.

The basis of the CAE-system (Figure 1) is connected in a single complex: a knowledge base, database, analytical subsystem and a software module used by the technologist for the calculations necessary for the implementation of a specific technological process.

The knowledge base is a systematic repository that combines all types of information needed by a process engineer to make sound and rational decisions during the development of the hardening and/or restoration process. The search for relevant information in the knowledge base is optimized based on typical operating scenarios. 


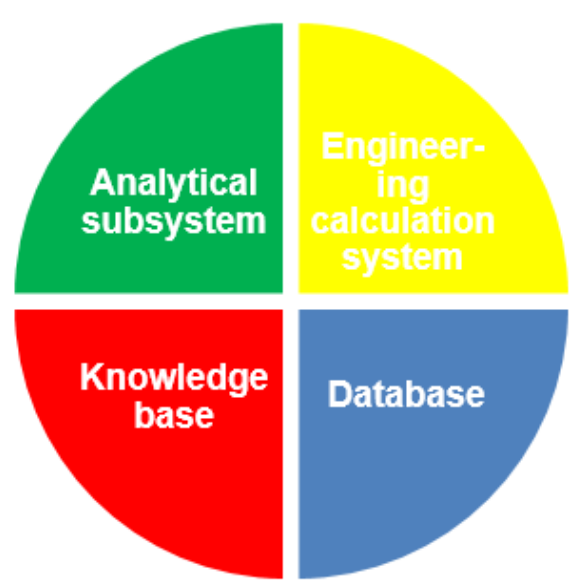

Fig. 1. Proposed CAE-system main modules

The database includes all the formalized data used by the process engineer and research engineer in the work.In general, when determining the properties of a coating, the actual operating conditions are modelled by the conditions of experiments and the parameters of the real part are measured by the parameters of the test specimen with a sprayed coating. Thus, the actual operational properties of gasthermal coatings are described by a multidimensional value space. A coating with specified properties is formed during the gas-thermal spraying process, which is described by 3 main groups of parameters: parameters of the spraying process, properties of the sprayed material and properties of the sprayed powder. The database should include the following experimental data:

- physical, chemical and mechanical characteristics of materials from various literary sources;

- physical, chemical and mechanical properties of gas-thermal coatings from various literature sources, as well as those obtained during the experiments.

The analytical subsystem is a bundled and integrated with the database set of tools and methods used to search for relationships in large data arrays.These families of methods are called Datamining. It is of interest to use these methods by research engineers to heuristically analyse the contents of the database and determine potentially interesting research directions in the development of new coatings and ways to increase the efficiency of thermal spray technological processes.

The engineering calculation system is used by the technologist to make the calculations necessary for the development and implementation of a specific technological process.

\section{Results and discussion}

The developed CAE-system is a software package that allows the technologist to implement based on the technical specifications for the hardening and/or restoration of parts:

- choice of material and structure of the coating;

- selection of the optimal coating method;

- development of hardening and/or restoration process.

Based on the analysis made by the authors, it was revealed that the knowledge base (Figure 2) should consist of 5 clusters with the following conditional names: "Science and technology", "Community thermal spraying", "Technical and software", "Coatings usage", "Materials and coatings".

As the analysis shows, for a full description of gas-thermal coatings, it is necessary to use 64 parameters, which are in fact properties of the coating. At the same time, most of the properties are variable values depending on the operating conditions and parameters of the coated part (Figure 3).

Generally, the data included in the database are given in sources without specifying the equipment on which the data were obtained, the accuracy of measurements, sometimes even without the conditions in which the tests were conducted. The most obvious and often similar problems are found in the tables of qualitative properties. So, for example, the record that the coating has high corrosion resistance does not make sense, if the environment in which the tests were carried out is not described. 
It also very rarely provides information on how to build quality scales. For example, it is likely that different experiments have used different boundaries between the "good" and "satisfactory" categories.

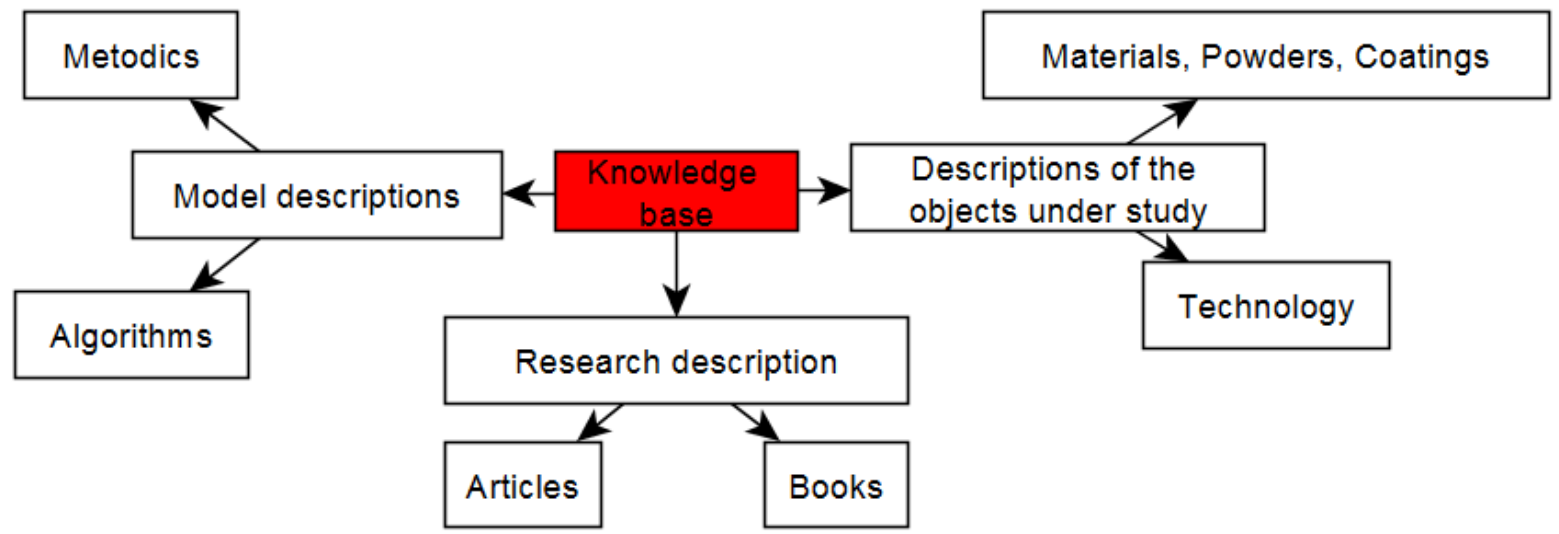

Fig. 2. Integrated knowledge base structure

During the process of plasma spraying, physicochemical processes are essentially heterogeneous in nature and duration of the process occurs at the macro, micro, and nanolevels. Because of this, the same object involved in the process of plasma spraying must be considered at various levels and in conjunction with other objects. For example, the chemical composition of the starting materials can be judged only on the potential use of coatings that can be obtained from them. Moreover, to fully describe the properties of the initial powders and determine the possibility of their use for coating in each specific case, it is also necessary to consider the size, shape, distribution of particles and the homogeneity of the chemical composition of the powder.In order to clarify the situation with the ambiguity of the properties of gas-thermal coatings, the structure of the database being developed presents the covering property as the result of anvirtual numerical experiment.

Based on the proposed knowledge base and database concept the program "Plasma Data Expert" was developed and patented [49]. The program is designed to collect, centralize and for heuristic analysis of technological data used in the development of the technological process of restoration and hardening of engineering parts. The program provides support to the process engineer and research engineer in the field of gas-thermal spraying at all key stages of work and allows to solve the following tasks:

- intuitive collection and automatic systematization of all formalized data used by the process engineer and research engineer in the work;

- search and evaluation of the suitability of existing technological processes, potentially suitable for the implementation of a specific technical specification for the restoration and/or hardening of the part;

- search and provide relevant source data for the program for the selection and synthesis of equipment and technological means for the implementation of the technological process of spraying;

- search for relevant, practically significant and new scientifically-oriented directions for conducting research in the field of gas thermal spraying technology;

- analysis of experimental data in the field of gas-thermal spraying using modern methods of intelligent information processing and automated search for analytical dependencies.

The program is implemented as a Web application running on a server computer. The program includes a databaseand provides structuring of the data stored in it in the form of a single graph according to specially developed algorithms. Due to this special structuring, the program allows for heuristic data analysis using plug-in separate Data Mining tools. The results of the analysis are further used to search for analytical dependencies using genetic algorithms and symbolic regression modules included in analytical subsystem (Figure 4). 


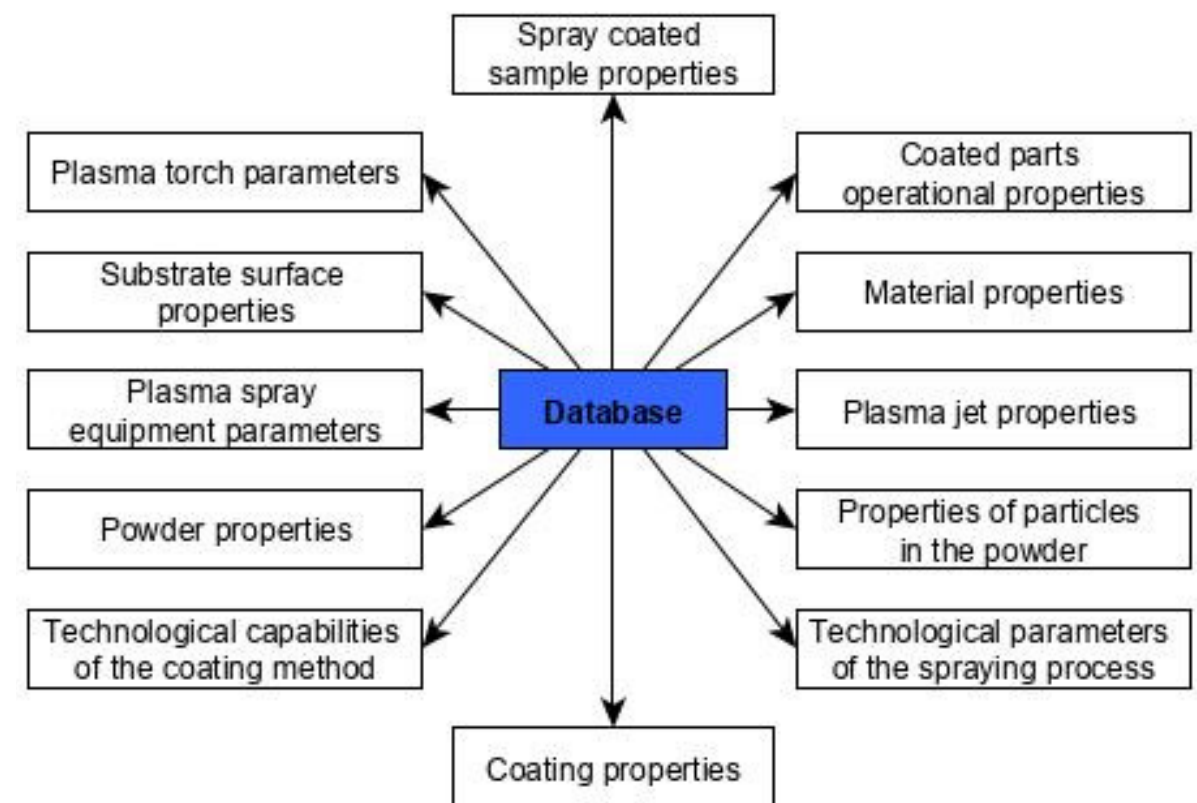

Fig. 3. Integrated database structure

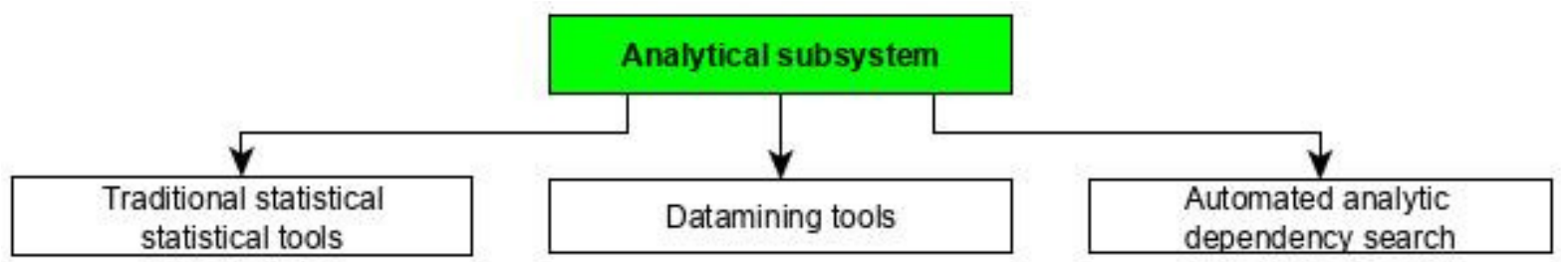

Fig. 4. Integrated structure of analytical subsystem

Also, on the basis of the researches provided by the authors, the program "PT Material Heuristic" [50] was developed and patented, designed to collect and structure the properties of materials and coatings used to restore and/or harden parts of agricultural machinery and processing equipment of the agro-industrial complex.

Conceptually, the program is a production knowledge base and provides structuring of the data stored in it as a single graph using special algorithms and further clustering using Kohonen neural networks and searching for analytical dependencies using Analytical subsystem (Figure 4).

The program operates with the following basic experimental data:

- physical, chemical and mechanical characteristics of materials from various literary sources;

- physical, chemical and mechanical properties of gas-thermal coatings from various literary sources, as well as those obtained during the experiments;

- technological regimes and conditions under which gas-thermal coatings were (or should be) obtained;

- information about the conditions - "context", in which the above characteristics of the starting materials and coatings retain their adequacy and applicability.

The engineering calculation system (Figure 5) consists of several program blocks, each of which performs a specific, logically perfect set of functions. The element of the engineering calculation system representing the greatest scientific complexity is the block for calculating the technological modes of plasma spraying of coatings. This block is based on a mathematical model of the plasma spraying process developed by the authors.

The second responsible, complex and knowledge-intensive task requiring solution is the choice of a rational coating material, which uses a database and allows a heuristic analysis and selection of several most appropriate coating material options. 


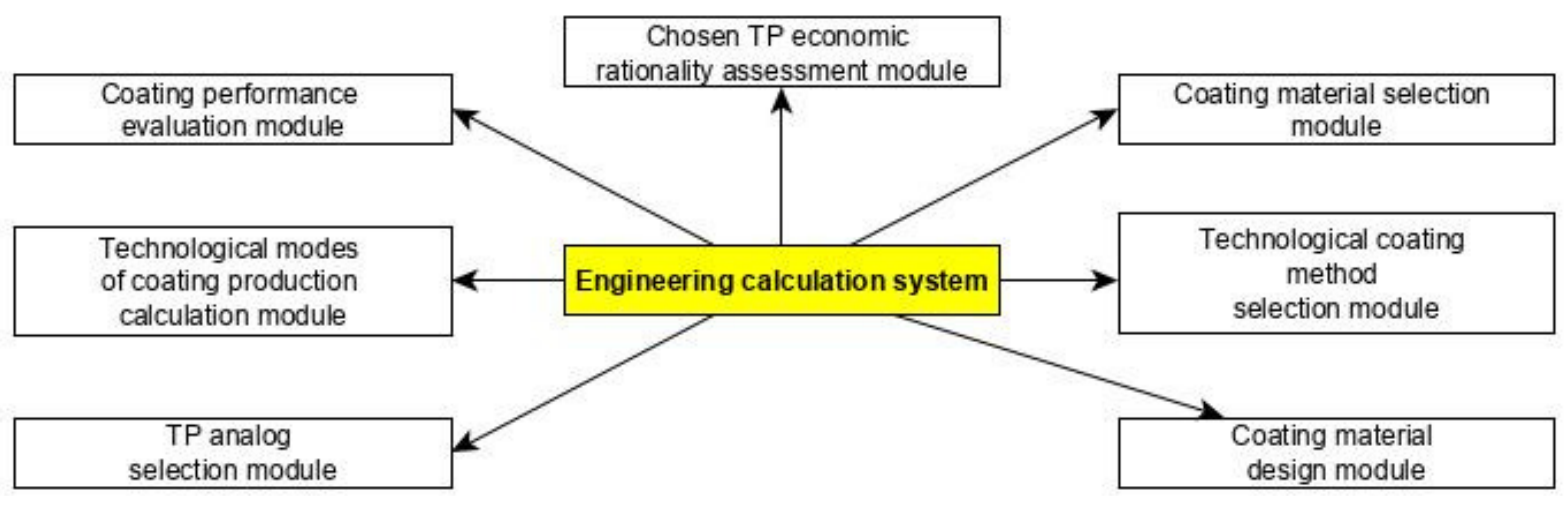

Fig. 5. Integrated structure of engineering calculation system

For practical implementation of the Engineering calculation system, the following software products were developed and patented: "System for calculating and optimizing technological modes of applying protective coatings" Protection "(RP" Protection ") [51]," Optimizing technological methods for applying strengthening coatings (TST Optimal Renovation)"[52] and "Optimization of technological regimes for applying protective coatings by plasma methods (TST Plasma Renovation)" [53] based on the previously developed mathematical models and algorithms presented in Chapter 2 of this work.

The developed programs consist of the following program modules intended for:

- choosing the material for coating;

- constructing the coating structure;

- selecting the optimal technological method of coating;

- calculation of technological modes of plasma spraying of coatings;

- assessing the economic rationality of the selected process;

- optimization of the technological mode of spraying to achieve maximum economic rationality of the developed process while maintaining the required properties and performance characteristics of the resulting coating;

- assessing the performance of the coated part.

The developed programs form the submitted engineering calculation system allow based on the technical specifications for hardening and/or restoring parts of agricultural equipment and processing equipment of the AICto execute:

- choose the material and structure of wear-resistant, erosion-resistant and corrosion-resistant coatings;

- technical and economic analysis of methods for applying hardening coatings;

- selection of the optimal method of applying hardening coatings;

- calculation and optimization of the technological modes of hardening and/or restoration of the part by the method of plasma spraying.

The described programs are developed on Ruby programming language, work on stand-alone PCs underWindows-and Linux based operation systems with the following minimum system requirements: IBM PC 1GHz CPU, 512 Mb RAM, 4 GB HDD.

The scientific novelty of all five developed programs is confirmed by state certificates of registration of computer programs issued by the patent authorities of the Russian Federation [49-53].

Figure 6 shows the integrated CAE-systemwith its interaction with the process engineer. 


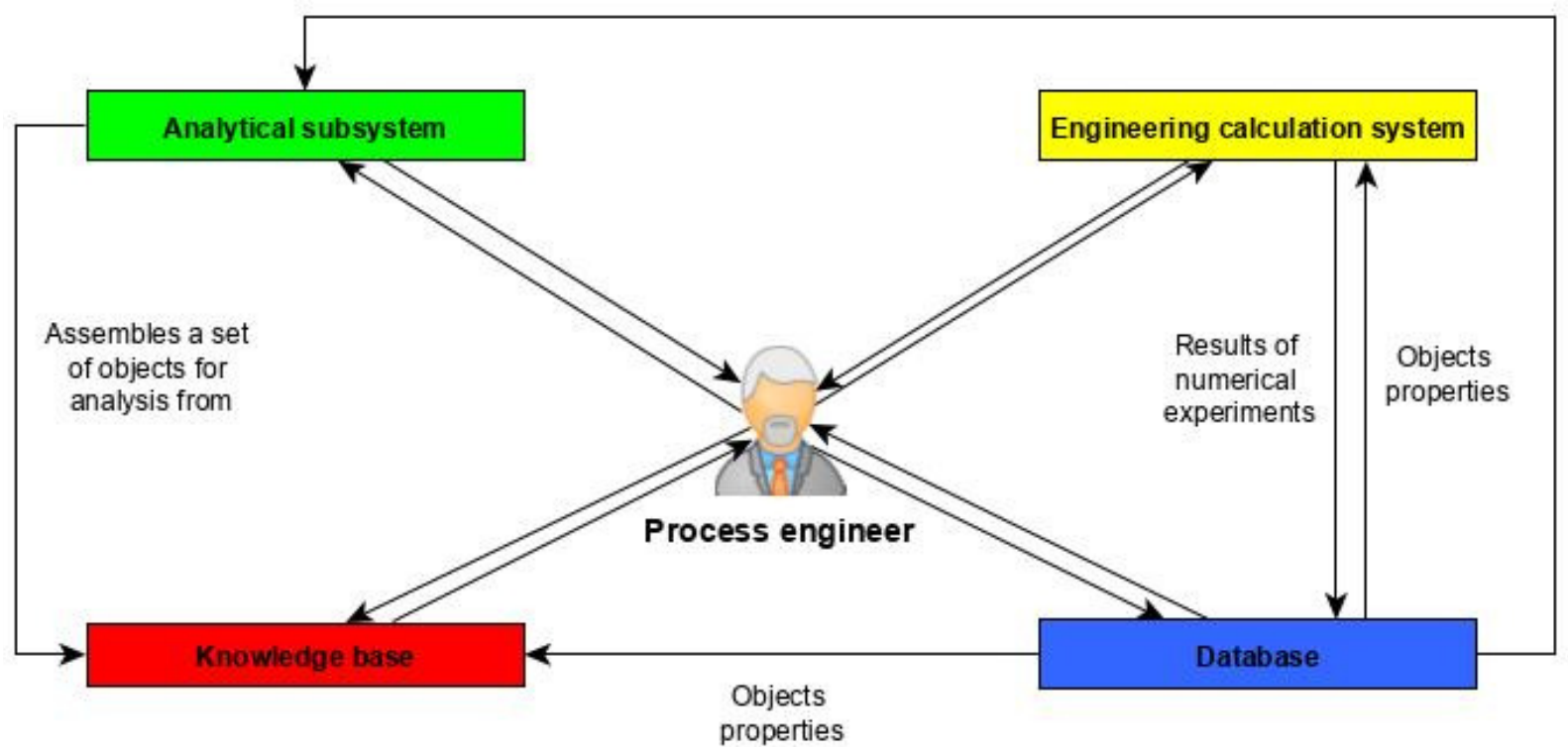

Fig. 6. Integrated structure of proposed CAE-system

\section{Conclusions}

The application of the proposed intelligent CAE-system can significantly reduce the cost of developing of resource-savingtechnologies (technological processes and equipment) for reconditioning and hardening of AIC processing equipment parts, improve their quality, and increase the productivity of designers and technologists. The software package implemented at the same time makes it possible to effectively carry out computational experiments for a comprehensive study and forecasting of the obtained coatings of various functional purposes with enhanced physical, mechanical and operational properties.

\section{References}

[1] Батищев А.Н., Чижикова Т.В., Голубев И. Г. и др. Монтаж, эксплуатация и ремонт технологического оборудования перерабатывающих отраслей АПК : Справочник (Batischev A.N., Chizikova T.V, Golubev I.G. et al. Installation, operation and repair of technological equipment of processing branches of the agroindustrial complex: Handbook). Informagrotech, Moscow, 1997, 288 p. (In Russian).

[2] Кравченко И.Н., Пузряков А.Ф., Глинский М.А. и др. Инженерные методы обеспечения долговечности и надежности машин и технологического оборудования в промышленности.

Монография. (Kravchenko I.N., Puzryakov A.F, Glinskiy M.A. et al. Engineering methods to ensure the durability and reliability of machines and process equipment in industry. Monograph). "Eco-Press" Publishing, Moscow, 2011, 424 p., ISBN 978-5-904301-61-3. (In Russian).

[3] Пузряков А.Ф., Ставровский М.Е., Олейник А.В. и др. Технологические процессы в сервисе: учебное пособие. (Puzryakov A.F., Stavrovskiy M.E, Oleynik A.V. et al. Technological processes in the service: Tutorial). INFRA-M Publishing, Moscow, 2011, 240 p.. (In Russian).

[4] Черноиванов В.И., Лялякин В.П., Голубев И.Г. Организация и технология восстановления деталей машин: науч. издание (Chernoivanov V.I., Lyalyakin V.P, Golubev I.G. Organization and technology of restoration of machine parts: scientific edition). FGNU "Rosinformagrotech", Moscow, 2016, 568 p. (In Russian).

[5] Черноиванов В.И., Северный А.Э., Кричевский М.Е. и др. Проблемы технического сервиса в АПК России: монография (Chernoivanov V.I., Severniy A.E, Krichevskiy M.E. et al. Problems of technical service in the agricultural sector of Russia: monograph). All-Russian Scientific Research Technological Institute of Repair and Operation of the Machine-Tractor Park of the Russian Agricultural Academy, Moscow, 2000, 309 p. (In Russian).

[6] Иванов В.П., Вигерина Т.В. Источники экономической эффективности ремонтновосстановительного производства (Ivanov V.P., Vigerina T.V. Sources of economic efficiency 
of repair and restoration production). Proceedings of GOSNITI, Vol. 130, 2018, pp. 265-270. (In Russian).

[7] Лялякин В.П. Перспективы восстановления деталей сельскохозяйственной техники (Lyalyakin V.P. Prospects for the restoration of parts of agricultural machinery). Proceedings of Rosinformagrotech, 2017, pp. 473-477. (In Russian).

[8] Михальченков А.М., Соловьев С.А., Михальченкова М.А. Развитие инновационных технологий при оказании сервисных услуг для поддержания надежности сельскохозяйственной техники (Mikhalchenkov A.M., Soloviev S.A., Mikhalchenkova M.A. Development of innovative technologies in the provision of services to maintain the reliability of agricultural machinery). Strengthening technologies and coatings, No 11, 2014, p. 1722. (In Russian).

[9] Соловьев С.А., Герасимов В.С. Развитие инновационных технологий при оказании сервисных услуг для поддержания надежности сельскохозяйственной техники (Soloviev S.A., Gerasimov V.S. Development of innovative technologies in the provision of services to maintain the reliability of agricultural machinery). Collection of scientific reports of the International Scientific and Technical Conference Innovative development of the agro-industrial complex of Russia based on intelligent machine technologies, Moscow, September 17-18th, 2014, No 2 (22), pp. 20-23. (In Russian).

[10] Fauchais P., Vardelle M., Goutier S. Latest Researches Advances of Plasma Spraying: From Splat to Coating Formation. Journal of Thermal Spray Technology. Volume 25, issue 8, December 2016, pp. 1534-1553.

[11] Khor K.A., Yu L.G. Global Research Trends in Thermal Sprayed Coatings Technology Analyzed with Bibliometrics Tools. Journal of Thermal Spray Technology. Volume 24, issue 8, December 2015, pp. 1346-1354.

[12] Berndt C.C., Brindley W., Goland A.N. et al. Current Problems in Plasma Spray Processing. Journal of Thermal Spray Technology, Volume 1 (4), December 1992, p. 341.

[13] Dapkunas S.J. NIST Ceramics Coatings Program. Thermal Spray Workshop on Sensors, Modeling and Control Strategies: Conference proceedings, Gaithersburg, November 19th, 1998.

[14] Jankovic M., Mostaghimi J., Noga J.O. Mathematical Modeling in Thermal Plasma Spraying. Developments and Applications of Ceramics and New Metal Alloys: Conference proceedings, Canadian Institute of Mining, Metallurgy and Petroleum: Montreal, Quebec, Canada, August 29th - September 2nd, 1993, pp. 487-501.

[15]Lugscheider E., Banmani C., Eckert P. et al. Modeling of the APS Plasma Spray Process. Computational Material Science: Computational Modeling of the Mechanical Behavior of Materials: Conference proceedings, Aachen, Germany, November 27-29th, 1995, Vol. 7 (No. 12), Dec. 1996, pp. 109-114.

[16] Pfender E. Advances in Modeling of the Thermal Spray Process. Journal of Thermal Spray Technology, Volume 6 (2), June 1997, pp. 126-128.

[17] Tani K., Nakahira H. Status of Thermal Spray Technology in Japan. Journal of Thermal Spray Technology, Volume 1 (4), December 1992, pp. 333-339.

[18]Ba T., Kang C.W., Ng N.W. Numerical Study of the Plasma Flow Field and Particle In-flight behavior with the Obstruction of a Curved Substrate. Journal of Thermal Spray Technology, Volume 18 (5-6), Mid-December 2009, pp. 858-874.

[19] Bolot R., Coddet C., A. Allimant et al. Modeling of the Plasma Flow and Anode Region Inside a Direct Current Plasma Gun. Journal of Thermal Spray Technology, Vol. 20, Issue 1-2, January 2011, pp. 21-27.

[20] Borisov Yu., Bushma A., Krivtsun I. Modeling of Motion and Heating of Powder Particles in Laser, Plasma and Hybrid Spraying. Journal of Thermal Spray Technology, Vol. 15 (4), December 2006, pp. 553-558.

[21] Cetegen B.M., Basu S. Review of Modeling of Liquid Precursor Droplets and Particles Injected into Plasmas and High-Velocity Oxy-Fuel (HVOF) Flame Jets for Thermal Spray Deposition Applications. Journal of Thermal Spray Technology, Vol. 18 (5-6), Mid-December 2009, pp. 769793. 
[22] Chazelas C., Moreau E., Mariaux G. et al. Numerical Modeling of Arc Behavior in a DC Plasma Torch. Laboratoire Sciences des Procedes Ceramiques et de Traitements de Surface, ENSIL: Limoges Cedex, France. High Temperature Materials Processing, 10(3), 2006, pp. 393-406.

[23] Duan Z., Beall L., Schein J. et al. Diagnostics and Modeling of an Argon/Helium Plasma Spray Process. Journal of Thermal Spray Technology, Vol. 9 (2) June 2000, pp. 225-234.

[24]Fukuhama H., Huang R., Tanaka Y. et al. Mathematical Modeling and Numerical Simulation of Splat Cooling in Plasma Spray Coatings. Journal of Thermal Spray Technology, Vol. 18 (5-6) Mid-December 2009, pp. 965-974.

[25] Guessasma S., Montavon G., Coddet C. Modeling of the APS Plasma Spray Process Using Artificial Neural Networks: Basis, Requirements and an Example. Computational Materials Science, 29 (3), 2004, pp. 315-333.

[26] Honner M., Sroub J. Modeling of Thermal Spraying Heat Transfer Processes by Exodus Stochastic Method. Journal of Thermal Spray Technology, Vol. 18 (5-6) Mid-December 2009, pp. 1014-1021.

[27] Ivoseric M., Cairncross R.A., Knight R. 3D Predictions of Thermally Sprayed Polymer Splats: Modeling Particle Acceleration, Heating and Deformation on Impact with a Flat Substrate. International Journal of Heat and Mass Transfer, 49(19-20), September 2006, pp. 3285-3297.

[28] Jean M. D., Lin B.T., Chou J.H. Application of an Artificial Neural Network for Simulation Robust Plasma-Sprayed Zirconia Coatings. Journal of American Ceramic Society, 91 (5), 2008, pp. 1539-1547.

[29] Kanta A.F., Montavon G., Vardelle M. et al. Artificial Neural Networks vs. Fuzzy Logic: Simple Tools to Predict and Control Complex Processes - Application to Plasma Spray Processes. Journal of Thermal Spray Technology, Vol. 17(3), September 2008, pp. 365-376.

[30] Li H.-P., Pfender E. Three-Dimensional Modeling of the Plasma Spray Process. Journal of Thermal Spray Technology, Vol. 16 (2), June 2007, pp. 245-260.

[31]Liu B., Zhang T., Bao Y. et al. Numerical Modeling of Motion and Heating of Particles During Plasma Spraying. School of Engineering, Kingston University, London, United Kingdom. Surface Engineering, 18(5), 2002, pp. 350-357.

[32] Mostaghimi J., Chandra, R. Ghafouri-Azar S. et al. Modelling Thermal Spray Coating Processes: A Powerful Tool in Design and Optimization. Surface Coating Technology, 163-164, 2003, pp. 111.

[33] Trelles J. P., Chazelas C., Vardelle A. et al. Arc Plasma Torch Modeling. Journal of Thermal Spray Technology, Vol. 18(5-6), Mid-December 2009, pp. 749-750.

[34]Zagorskiy A.V., Stadelmaier F. Full-Scale Modeling of a Thermal Spray Process. ALSTOM Power Technology, Baden-Daetwill, Switzerland. Surface Coating Technology, 2001, pp. 162167.

[35]Zhainakov A., Urusov R., Valeeva A.; edited by Solonenko O.P. Modelling of Electric Arc Plasma: Thermal Plasma Torches and Technologies. Cambridge International Science Publishing, Cambridge, Vol. 1: Plasma Torches. Basic Studies and Design, 2003, pp. 197-205.

[36] Chazelas C., Trelles J.P., Vardelle A. The Main Issues to Address in Modeling Plasma Spray Torch Operation. Journal of Thermal Spray Technology, Vol. 26 (1-2). January 2017, pp. 3-11.

[37]Bobzin K., Öte M., Schein J. et al. Modelling the Plasma Jet in Multi-Arc Plasma Spraying. Journal of Thermal Spray Technology. Volume 25, issue 6, August 2016, pp. 1111-1126.

[38] Alaya, M., Chazelas C., Vardelle A. Parametric Study of Plasma Torch Operation Using a MHD Model Coupling the Arc and Electrodes. Journal of Thermal Spray Technology, Vol. 25, Issue 12, January 2016, pp. 36-43.

[39] Bobzin K., Öte M., Schein J. et al. Modelling the Plasma Jet in Multi-Arc Plasma Spraying. Journal of Thermal Spray Technology, Vol. 25, Issue 6, August 2016, pp. 1111-1126.

[40] Bobzin K., Öte M. Modeling Plasma-Particle Interaction in Multi-Arc Plasma Spraying. Journal of Thermal Spray Technology, Vol. 26, Issue 3, February 2017, pp. 279-291.

[41] Guessasma S., Montavon G., Gougeon P. et al. Designing Expert Systems Using Neural Computation in View of the Control of Plasma Spray Processes. Material Design, 24 (7), 2003, pp. 497-502.

[42] Trifa F.-I., Montavon G., Coddet C. Model-Based Expert System for Design and Simulation of APS Coatings. Journal of Thermal Spray Technology, Vol. 16 (1), March 2007, pp. 128-139. 
[43] Mauer G., Rauwald K.-H., Mücke R. et al. Monitoring and Improving the Reliability of Plasma Spray Processes. Journal of Thermal Spray Technology, Vol. 26, Issue 5, June 2017, pp. 799-810.

[44]Глинский М.А. Пузряков А.Ф. Математическая модель нагрева частиц с высокой теплопроводностью в плазменной струе (Glinskiy M.A. Puzryakov A.F. Mathematical model of heating of particles with high thermal conductivity in a plasma jet). Proceedings of the XXXV Academic readings in cosmonautics "Actual problems of the Russian cosmonautics", N.E. Bauman MSTU Publishing, Moscow, 2011, p 572. (In Russian).

[45]Глинский М.А., Кравченко И.Н., Бобряшов Е.М. и др. Методика проектирования технологических процессов нанесения плазменных покрытий на основе применения безразмерных комплексных критериев (Glinskiy M.A. Kravchenko I.N., Bobryashov E.M. et al. Metodic of designing technological processes of applying plasma coatings based on the dimensionless complex criteria usage). Repair. Recovery. Modernization: a monthly production, scientific, technical and educational journal., 2011, № 5, pp. 32-34. (In Russian).

[46]Глинский М.А., Кочаров Г.Р., Пузряков А.Ф. Разработка автоматизированной инженерной системы (САЕ-системы) проектирования покрытий и технологических процессов упрочнения и восстановления деталей машиностроения с использованием плазменного напыления (Glinskiy M.A., Kocharov G.R., Puzryakov A.F. Development of an automated engineering system (CAE-system) for the design of coatings and technological processes for hardening and restoring engineering parts using plasma spraying). Rapidly hardened materials and coatings: Proceedings of the 11th All-Russian Scientific and Technical Conference with international participation., K.E. Tsiolkovskogo MATI, Moscow, 2012, pp. 159-169. (In Russian).

[47]Глинский М.А., Кравченко И.Н. Разработка плазменных покрытий и технологических процессов их нанесения с использованием автоматизированной инженерной системы (Glinskiy M.A., Kravchenko I.N. Development of plasma coatings and technological processes of their deposition using an automated engineering system). Proceedings of the International Scientific and Technical Conference "Perspective approaches and technologies of design and production of parts and products of aerospace engineering", Moscow, November 1st-2nd, 2017, pp. 22-29. (In Russian).

[48]Глинский М.А., Кравченко И.Н., Шамарин Ю.А. и др. Разработка технологии нанесения плазменных покрытий многофункционального назначения (Glinskiy M.A., Kravchenko I.N., Shamarin Yu.A. et al. Development of a technology for applying multifunctional plasma coatings). Scientific journal: Bulletin of the Moscow State Agricultural Engineering University named after V.P. Goryachkina, No 6 (82), 2017, pp. 63-71. DOI: 10.26897/1728-7936-2017-663-71. (In Russian).

[49] System for collecting and heuristic analysis of technological data "Plasma Data Expert" (Program "Plasma Data Expert"). Certificate of Russian Federation State Registration of Computer Program No 2011618601 Authors: Glinskiy M.A., Morozov A.A., Puzryakov A.F. and others. Applicants and rightsholders: Glinskiy M.A., Morozov A.A. Application No 2011616820. Declared: September 13th, 2011. Registered: November 11th, 2011.

[50] "RT Material Heuristic". Certificate of Russian Federation State Registration of Computer Program No 2017619785. Authors: Glinskiy M.A., Kravchenko I.N., Pupavtsev I.E. and others. Applicant and rightsholder: Federal State-Financed Educational Institution of Higher Education "Russian State Agrarian University - Moscow State Agricultural Academy K.A. Timiryazeva. Application No 2017616626. Declared: July 6th, 2017. Registered: September 6th, 2017.

[51] System for calculating and optimizing technological regimes for applying protective coatings "Protection" (RP "Protection"). Certificate of Russian Federation State Registration of Computer Program No 2012610041 Authors: Glinskiy M.A., Morozov A.A., Kravchenko I.N. and others. Applicants and rightsholders: Glinskiy M.A., Morozov A.A. Application No 2011618042. Declared: October 28h, 2011. Registered: January 10th, 2012.

[52] Optimization of technological methods for applying hardening coatings (TST Optimal Renovation). Certificate of Russian Federation State Registration of Computer Program No 2017619328. Authors: Glinskiy M.A., Kravchenko I.N., Cheha T.A. and others. Applicant and rightsholder: Federal State-Financed Educational Institution of Higher Education "Russian State 
Agrarian University - Moscow State Agricultural Academy K.A. Timiryazeva. Application No 2017616076. Declared: June 26th, 2017. Registered: August 22nd, 2017.

[53] Optimization of technological regimes for applying protective coatings by plasma methods (TST Plasma Renovation). Certificate of Russian Federation State Registration of Computer Program No 2017619358. Authors: Glinskiy M.A., Kravchenko I.N., Korneev V.M. and others. Applicant and rightsholder: Federal State-Financed Educational Institution of Higher Education "Russian State Agrarian University - Moscow State Agricultural Academy K.A. Timiryazeva. Application No 2017615973. Declared: June 26th, 2017. Registered: August 24th, 2017. 